\title{
Effects of Intraguild Predation: Evaluating Resource Competition between Two Canid Species with Apparent Niche Separation
}

\author{
Adam J. Kozlowski, ${ }^{1}$ Eric M. Gese, ${ }^{1,2}$ and Wendy M. Arjo ${ }^{3}$ \\ ${ }^{1}$ Department of Wildland Resources, Utah State University, Logan, UT 84322, USA \\ ${ }^{2}$ U.S. Department of Agriculture, Wildlife Services, National Wildlife Research Center, Logan, UT 84322, USA \\ ${ }^{3}$ AGEISS Environmental, 1617 Ontario Street SE, Olympia, WA 98501, USA
}

Correspondence should be addressed to Eric M. Gese, eric.gese@usu.edu

Received 23 May 2011; Accepted 25 August 2011

Academic Editor: Andrew Sih

Copyright ( $) 2012$ Adam J. Kozlowski et al. This is an open access article distributed under the Creative Commons Attribution License, which permits unrestricted use, distribution, and reproduction in any medium, provided the original work is properly cited.

\begin{abstract}
Many studies determine which habitat components are important to animals and the extent their use may overlap with competitive species. However, such studies are often undertaken after populations are in decline or under interspecific stress. Since habitat selection is not independent of interspecific stress, quantifying an animal's current landscape use could be misleading if the species distribution is suboptimal. We present an alternative approach by modeling the predicted distributions of two sympatric species on the landscape using dietary preferences and prey distribution. We compared the observed habitat use of kit foxes (Vulpes macrotis) and coyotes (Canis latrans) against their predicted distribution. Data included locations of kit foxes and coyotes, carnivore scat transects, and seasonal prey surveys. Although habitats demonstrated heterogeneity with respect to prey resources, only coyotes showed habitat use designed to maximize access to prey. In contrast, kit foxes used habitats which did not align closely with prey resources. Instead, habitat use by kit foxes represented spatial and behavioral strategies designed to minimize spatial overlap with coyotes while maximizing access to resources. Data on the distribution of prey, their dietary importance, and the species-specific disparities between predicted and observed habitat distributions supports a mechanism by which kit fox distribution is derived from intense competitive interactions with coyotes.
\end{abstract}

\section{Introduction}

Theorists of competition between animal species have long recognized the important role resources play in shaping the ecology of a species [1-3]. Today, with declines in animal populations being attributed to widespread loss of suitable habitat, many studies focus on determining the resources important to imperiled species and the extent resource use overlaps with competing species [4, 5]. Habitat degradation, resulting in the potential loss of distinct niche space, may increase the potential for competition between sympatric species $[6,7]$. As resource overlap increases, species often rely on behavioral mechanisms to reduce competitive pressures [8-10]. Evidence of a species' effort to isolate its niche frequently manifests itself as changes in the use of space, time, or food resources and is often accompanied by restricted distribution, decreased fitness, or a reduction in popula- tion size [11-13]. When studied for relatively short periods of time or without historical perspective, two species competing for the same resources are coexisting because of the employment of these isolation mechanisms.

Often, studies examining the effects of competition are initiated for populations which have already incorporated behavioral changes, or are even in decline, as a result of interspecific pressures (e.g., [12-14]). Since a species' habitat selection is not independent of such pressures, quantifying resource use versus availability may give a false impression of optimal distribution and resource requirements $[15,16]$, although habitat selection may occur in response to other intrinsic and extrinsic factors (e.g., thermoregulation, energetics, prey choice). Management decisions based on apparent interspecific species compatibility, as indicated by nonoverlapping habitat use patterns, may be in error. To test whether declining species are distributed optimally with 
regards to resources, an alternative solution would be to model the predicted distributions of sympatric species.

Research conducted on the resource overlap of kit foxes (Vulpes macrotis) and coyotes (Canis latrans) on Dugway Proving Ground (Dugway), Utah, demonstrated significant differences in the canids' use of space, but only moderate differentiation of their diets [17]. Compared to historical distribution data collected on Dugway's kit foxes in the 1960's and 1970's [18, 19], population density of kit foxes has decreased [14] and distribution patterns have changed across the study area including habitats where foxes place their dens [20]. Based upon the high level of resource overlap (diet, space, and time) between kit foxes and coyotes [17], our objective in this paper is to provide a conceptual starting point for identifying the effects of competitive exclusion. We built upon the descriptive data [17] by developing a simple model of the predicted distribution of these two sympatric canids from measures of prey abundance and distribution across the shared landscape and comparing the predicted and observed distributions. Successful management of kit foxes requires determining if their spatial distribution is shaped by underlying resource patterns (choice) or interspecific carnivore interactions (force). If present, evidence for competitive interactions might exist in the differences between the observed and predicted canid distributions. While other factors may also influence distribution of these canids (e.g, substrate for dens, microclimate in various habitats), we focused on prey abundance and distribution as the main driver of habitat selection in this desert ecosystem.

\section{Materials and Methods}

2.1. Study Site. We conducted research on the Dugway Proving Ground (DPG), Utah, in the Great Basin ecosystem. Classified as a basin and range landscape, the area is dominated by relatively flat, low-elevation habitat interspersed with steep mountains. Elevations range from 1,288 to $2,154 \mathrm{~m}$. Owing to its position in a double rain shadow, mean annual precipitation is $20.3 \mathrm{~cm}$ with evaporation exceeding precipitation all year. Limited free water exists in the form of 9 natural springs, but is augmented by water-catchment systems, sewage treatment lagoons, and housing irrigation [21]. DPG was established in 1942 as a remote site for testing chemical and biological weapons. With the cessation of open air testing in 1967, objectives now emphasize live fire exercises involving artillery, helicopters, and jet aircraft. Although exercises are limited to designated areas, maneuvers of troops and heavy equipment are facility wide. Continuous military activity on DPG over the last 50 years has prohibited many activities (e.g., recreational vehicle use, cattle grazing, predator control, hunting) that are prevalent on surrounding public and private lands.

Although DPG's plant community is classified as northern desert shrub [22], the interplay of elevation, soil moisture, and salinity dictate which plant community exists at a location. Intracommunity variation was found to be low, with clear differentiation between vegetation types. For purposes of this study, we identified 7 habitats: shrub-steppe, grassland, stable dune, greasewood, chenopod, pickleweed, and urban. We reclassified a digital vegetation map with $10 \mathrm{~m}$ resolution to reflect these 7 categories. Species compositions of these 7 habitats are described in order of decreasing elevation, with the exception of the urban habitat. We used the minimum convex polygon of all canid telemetry locations to estimate the relative proportion of each habitat within the study area.

The plant composition of the shrub-steppe habitat $\left(81 \mathrm{~km}^{2}, 13 \%\right)$ included juniper (Juniper osteosperma), big sagebrush (Artemisia tridentata), greasewood (Sarcobatus vermiculatus), horsebrush (Tetradymia glabrata), viscid rabbit brush (Chrysothamnus viscidiflorus), forbs, and native bunch grasses. The grassland habitat $\left(135 \mathrm{~km}^{2}, 21 \%\right)$, largely a product of increased fire frequency and disturbance, was dominated by cheatgrass (Bromus tectorum), tumbling mustard (Sisymbrium altissimum), and peppercress (Lepidium perfoliatum). Stable dunes $\left(120 \mathrm{~km}^{2}, 19 \%\right)$ were composed of four-wing saltbush (Atriplex canescens), greasewood, sage, horsebrush, viscid rabbitbrush, dune rabbitbrush (Chrysothamnus nauseosus var. turbinatus), and Indian rice grass (Stipa hymenoides). The greasewood habitat $\left(65 \mathrm{~km}^{2}, 10 \%\right)$ was characterized by large, monospecific stands of greasewood. Chenopod habitat $\left(107 \mathrm{~km}^{2}, 17 \%\right)$ was dominated by gray molly (Kochia americana) and shadscale (Atriplex confertifolia), with some greasewood. Indicator species of the pickleweed habitat $\left(124 \mathrm{~km}^{2}, 19 \%\right)$ were Gardner's saltbush (Atriplex gardneri) and pickleweed (Allenrolfea occidentalis); both specialized for wet, saline conditions. Urban habitat $\left(5 \mathrm{~km}^{2}, 1 \%\right)$, being anthropomorphic in origin, was characterized by residential and industrial structures, office buildings, laboratories, debris, and paved surfaces, as well as nonnative plants including Russian olive (Elaeagnus angustifolia), tamarisk (Tamarix ramosissima), and lawn.

2.2. Animal Capture. We used helicopter net gunning to capture coyotes [23, 24]. We used box and enclosure traps to capture kit foxes [25]. For both species, no chemical immobilization was used to process animals. Animals $>1$-yr-old were radio collared, ear tagged, and released at the site of capture.

2.3. Observed Canid Distributions. We plotted locations of each radioed animal on the digital vegetation map to determine the habitat use of kit foxes and coyotes. Locations were from homing in on the radioed animal or triangulation obtained from ground and aerial telemetry. Repeated blind trials with reference collars determined ground telemetry error to be $<3^{\circ}$ and aerial telemetry error to average $<100 \mathrm{~m}$; the error polygon for a location had to be $<0.25 \mathrm{~km}^{2}$ to be retained for analyses [17]. We used the computer program Locate II (Pacer, Truro, Nova Scotia, Canada) to determine the animal's position from $\geq 3$ compass bearings [26]. We located animals 4 times a week for the life of the animal, or to the end of the 30-month study. We minimized sampling bias by evenly distributing observations across 4 time periods (dawn, day, dusk, night) and 3 seasons (breeding, rearing, dispersal) corresponding to distinct behavioral phases [2729]. We classed locations into day and night by monthly times for sunrise and sunset. 
We analyzed animal locations using ArcView 3.2 (Environmental Systems Research Institute, Inc., Redlands, Calif, USA) in combination with the digital vegetation map reclassified to represent the 7 habitat types. We buffered each location by $150 \mathrm{~m}$ in radius (larger than the size of the accepted error polygon of $0.25 \mathrm{~km}^{2}$ ) to define the area, not the point, the animal was using at the time of the location [17, 30, 31]. We employed the use of a buffer, whose length corresponded to the appropriate distance of awareness for the animals being studied, to more accurately represent space use [32, 33]. Standard analyses of telemetry data use computer algorithms (e.g., Locate II) to provide "best guess" coordinates and error polygons constructed from 3 bearings, or 2 bearings and a reference error. Researchers typically accept the "best guess" coordinates as the animal's actual location to apply to a home range estimate or assess landscape use parameters (e.g., habitat type, slope, aspect). This practice fails to recognize the resolution of radio telemetry location accuracy and can lead to misrepresentation of an individual animal's use patterns by incorporating arbitrary landscape. Individuals do not occupy space or make habitat use decisions based on a single dimension, as represented by a point location. More realistically, they exhibit some level of "awareness" for their surroundings through sight, smell, sound, and memory $[34,35]$. Approaching the analysis of landscape use by incorporating an animal's "awareness" shifts emphasis from use of a point location to an area of influence and preserves a more appropriate resolution of telemetry locations.

Animal awareness should be estimated separately for every species and should also account for site-specific landscape characteristics $[36,37]$. Based on visual observations $(n=513)$ of coyotes and kit foxes on DPG's open landscape, we estimated that $150 \mathrm{~m}$ was the average distance each species was immediately sensitive to its surroundings (i.e., became aware of an observers presence; $[30,31]$. We defined this distance as the species "awareness" which was used to convert point locations to a circular area $150 \mathrm{~m}$ in radius. We then used ArcView's Geoprocessing wizard extension to spatially join the buffered location to the habitat map. When summed over the course of the study, the corresponding polygons, infused with the proportions of habitats used, generated a 2dimensional use profile for each canid [17]. Because kit foxes traveled and hunted alone, and coyotes also traveled alone as indicated by activity patterns and spatial proximity, we used the individual animal as the sample unit for all analyses.

Although previous analyses of canid distributions on DPG focused on examining interactions between individuals with spatially overlapping home ranges [17], occurrence of coyotes on DPG and, therefore their use of habitat, were ubiquitous across the study site. For comparison with predicted distributions, space use by coyotes was portrayed on the population level. However, space use by kit foxes, because of their discontinuous distribution, was reported in the context of mountain, grassland, city, and poverty (i.e., lowlying salt flats) landscape classes based upon topography and elevation [17]. Due to a heterogeneous landscape, and in order to insure the comparison of the most spatially related canids with the highest chance of interaction $[26,38]$, we grouped individuals of both species into either a "highland" or "lowland" landscape class. Shrub-steppe, grassland, and stable dune habitats defined the highland regions of the study area, while the lowlands were composed primarily of greasewood, chenopod, and pickleweed habitats. Space use patterns allowed for the further division of kit foxes into 4 landscape use subclasses [17]. We divided highland foxes into "mountain" and "grassland" sub-classes, while lowland foxes were separated into "city" and "poverty". As well as focusing the analysis on the individuals with the highest potential for resource overlap, this strategy also examined habitat use at a finer scale than that of the study area, effectively reducing the confounding effects of habitat availability and its influence on the observed landscape use patterns of each species. As a result, differences in habitat use between study animals more closely reflected actual selection rather than differences in available habitat and prevented spurious comparisons of individual animals that did not overlap or occupy similar landscapes [17, 26, 38]. For both species, locations were pooled across years and seasons to provide an overall estimate of habitat use. However, the predicted distributions used the locations of individuals within each landscape class (see Section 2.6).

Comparisons between canid distributions were analyzed using a chi-square goodness-of-fit test [15]. For significant differences detected between distributions, we used Bailey simultaneous confidence intervals to determine if the observed use of habitat types was more or less frequent than the predicted use of each habitat type [39], as determined by prey distribution and abundance. We used Resource Selection for Windows (RSW) software to compute these comparative statistics [40].

2.4. Carnivore Diets. We collected and analyzed scats to determine both kit fox and coyote diets. Scats of these two sympatric canids were distinguished by size, shape, and odor $[41,42]$, as well as associated tracks and sign. We drove dirt road transects $(114 \mathrm{~km})$ monthly to collect scat for both species and clear the road for the next month's survey. Transects were distributed throughout the study area and passed through all 7 habitats. A vehicle with a driver and 2 observers drove transects in both directions before considering them clear. A low amount of fox scats on transects necessitated similar clearing and collection of scats at den sites. We classified transects and den sites as either highland or lowland based upon topography and elevation [17]. Once collected, scats were placed in paper bags labeled with month, species, and elevation. After being air dried, scats were transferred to nylon stockings, washed in a washing machine, and air dried. We analyzed indigestible remains using a light microscope for hair identification, and a locally obtained specimen collection for the identification of teeth, bones, and exoskeletons. Presence of individual prey species in each scat was recorded and percent occurrence calculated (no. of occurrences of an item/total no. of occurrences of all food items). We used the number of individuals observed in each prey category comprising $>10 \%$ of prey item occurrence to model canid distribution. While the size of each prey species varied, we used the occurrence of prey due to the lack of a biomass conversion for kit foxes and the major prey species in 
their diet. Future studies incorporating a biomass conversion for each prey species could prove useful.

2.5. Prey Distribution and Abundance. We quantified the relative abundance of black-tailed jackrabbits (Lepus californicus) and kangaroo rats (Dipodomys ordi and Dipodomys microps) across the habitat types using spotlight surveys $[43,44]$. Six road transects totaling $99 \mathrm{~km}$ were established in May 1999 and surveyed until August 2001. Spotlight transects overlapped but were not identical to scat transects. We conducted spotlight surveys in February, May, August, and November with each survey lasting 3 nights. All transects were driven each night, with at least 1 night between surveys to increase independence of locations. Surveys began 1 hour after sunset and consisted of 2 observers each using 1.5 million candle power spotlights to illuminate both sides of the road; vehicle speed was maintained at 16-24 kph. We recorded species, Universal Transverse Mercator (UTM) coordinates, and distance from the road for each individual observed; the distance for animals seen on the road was recorded as zero. Because of varying detection among habitats, we used strip transects with a maximum detection of $50 \mathrm{~m}$ for jackrabbits and $25 \mathrm{~m}$ for kangaroo rats to standardize the sampling area among all habitats (i.e., we used the lowest detection distance for all transects and habitats). We imported coordinates of observations into ArcView and overlaid them with the digital habitat map to determine the habitat class of each individual location. We calculated habitat availability by buffering each spotlight route by the detection distance ( $50 \mathrm{~m}$ for jackrabbits, $25 \mathrm{~m}$ for kangaroo rats) to produce a survey area. We used ArcView to determine the proportion of each habitat within each transects survey area.

We conducted small mammal trapping with Sherman live traps twice a year during prereproductive (June) and postreproductive (September) periods; 3 trapping grids were randomly placed in each habitat type. Each grid consisted of 64 traps placed $10 \mathrm{~m}$ apart in an $8 \times 8$ array. We baited each trap with peanut butter and oats, and each grid was active for a 4-night period. We baited and set traps just before dusk, then checked and closed them in the morning. Each animal captured was identified, weighed, sexed, and marked with black hair dye or a permanent marker before release.

We sampled nocturnal and diurnal insects using pitfall traps augmented with a drift fence [45]. Each pitfall array consisted of 3, $3 \mathrm{~m}$ arms arranged in a "Y". At the ends of the arms and at the center of the array, we buried steel cans $(15 \times$ $17 \mathrm{~cm}$ ) flush with the ground; 2 arrays were constructed in each of the habitats. We cleared the cans once in the morning and once at dusk for 3 days, allowing the identification of diurnal and nocturnal insect activity patterns. We operated the pitfall arrays at the end of the month, May-September, 1999 through 2001. Flush counts augmented invertebrate sampling by counting flying and hopping insects that were not susceptible to pitfall trapping [46]. One $50 \mathrm{~m}$ transect was measured off each corner of the 18 small mammal grids for a total of 4 transects per grid, 12 transects per habitat. We walked each transect once a month during the afternoon and recorded the number of lizards and insects flushing $\leq 2 \mathrm{~m}$ on either side of the observer, we walked transects during the same months the pitfall traps were operated.

2.6. Modeling the Predicted Canid Distributions. To determine if kit fox and coyote distribution patterns were being shaped by the heterogeneity of the underlying prey base (distribution by choice) or were instead being governed by interspecific carnivore interactions (distribution by force), we modeled "predicted" distributions for both canid species. Calculated from the distribution of prey populations and the diet of DPG's canids, predicted distributions of canid foraging represent spatial strategy alternatives where, in the absence of competition, kit foxes and coyotes maximize their proximity to abundant prey resources [47]. In addition, we present an overall landscape use unrestricted from competition by combining all canids from all landscape classes to produce a simplified, population-wide spatial budget for each of the species. Differences between observed spatial strategies of canids and modeled predicted distributions were used to quantify competition's role in shaping canid distribution on the landscape.

Proportions and rank of prey items in the diet of DPG's canids were determined from percent occurrence data from the scat analysis. We included only prey types occurring in the diet $\geq 10 \%$ of the time in the predicted distribution model. For both kit foxes and coyotes, 4 prey classes met this criterion: insect, rodent, kangaroo rat, and rabbit. For each of the 4 dominant prey types, the number of individuals enumerated per vegetation community was converted to a proportion of each habitat class to create a resource matrix linking habitat to prey abundance. Future studies incorporating a conversion of the number of individuals of each species to prey biomass in each habitat type could increase the precision of the model, but would require density estimates of each prey species in each habitat type as well as knowledge of detection probabilities for each survey method.

To model the spatial response of kit foxes and coyotes to DPG's prey matrix, we assumed that in the absence of competitive forces, canid populations would distribute themselves among vegetation types in proportion to the resources available to them [47-49]. Granted, other factors (e.g., prey vulnerability, temperature regimes, and soil types for dens) may have also influenced canid distribution, but we wanted to examine a relatively simple predictive model using prey distribution and abundance. The basic formula used to calculate the predicted distribution of canids was

$$
\text { Predicted distribution }=\sum_{j=1}^{v} \sum_{i=1}^{p}\left(A_{i j} D_{i}\right),
$$

Where $A_{i j}$ : Abundance of prey item $i$ found in vegetation class $j, D_{i}$ : Percent occurrence of prey item $i$ in diet, $p$ : Number of prey classes, and $v$ : Number of vegetation classes.

Starting with the proportional distributions of the 4 dominant prey classes as their base, the predicted distribution models weighted the contribution of each prey species to the matrix by its percent occurrence in the diet. Summing the weighted proportions across the 4 prey classes produced a coarse spatial budget for kit fox and coyote populations 
based solely on the distribution of prey classes and their prominence in the diet.

\section{Results}

3.1. Observed Canid Distributions. We captured and monitored 26 coyotes (14 males, 12 females) and 28 kit foxes (17 males, 11 females) between December 1999 and August 2001. Sixteen coyotes ( 10 males, 6 females) and 17 kit foxes ( 9 males, 8 females) had sufficient locations for spatial analysis (i.e., area-observation curves reached an asymptote). During the study, we collected 1,781 and 1,559 locations on kit foxes and coyotes, respectively; $>25 \%$ of these locations were visual observations during the set sampling time (i.e., mainly kit foxes lying on den mounds during the day). Continuous den monitoring and trapping efforts indicated that $90-95 \%$ of the kit foxes in the study area were captured and identified.

When averaged across the study area, coyotes (Figure 1(a)) showed preference for grassland $(P<0.0001)$, stable dune $(P<0.0001)$, and greasewood $(P<0.0001)$ habitat, with low but preferred use of urban areas $(P<0.001)$. Coyotes exhibited avoidance of chenopod $(P<0.0001)$, shrub-steppe $(P<0.0001)$, and pickleweed $(P<0.0001)$ habitats (Figure 1(a)).

Habitat use by kit foxes varied dramatically (Figure 1(b)). Although "Mountain" foxes avoided greasewood $(P<$ $0.0001)$, chenopod $(P<0.0001)$, pickleweed $(P<0.0001)$, and urban $(P<0.0001)$ habitats, their use of shrub-steppe $(P<0.0001)$ was greater than predicted. "Mountain" foxes used grassland $(P>0.05)$ and stable dune $(P>0.05)$ habitats not different from their availability on the landscape. "Grassland" foxes showed overwhelming preference for the grasslands $(P<0.0001)$, while avoiding greasewood $(P<$ $0.0001)$, chenopod $(P<0.0001)$, stable dune $(P<0.0001)$, pickleweed $(P<0.0001)$, and urban $(P<0.05)$ habitats; use of shrub-steppe $(P>0.05)$ habitat was not different than availability. "City" foxes showed preference for only the urban habitat $(P<0.0001)$, while using the greasewood $(P<$ $0.001)$, grassland $(P<0.0001)$, stable dune $(P<0.0001)$, shrub-steppe $(P<0.0001)$, and pickleweed $(P<0.0001)$ habitats less than predicted; use of chenopod habitat was not different than availability $(P>0.05)$. "Poverty" foxes spent more time than predicted in pickleweed $(P<0.0001)$ and urban $(P<0.0001)$ habitats, while avoiding grasslands $(P<$ $0.0001)$, shrub-steppe $(P<0.0001)$, and greasewood $(P<$ $0.0001)$. "Poverty" foxes use of chenopod $(P>0.05)$ and stable dunes $(P>0.05)$ did not differ from their availability (Figure 1(b)).

3.2. Prey Distribution and Abundance. A total of $2,970 \mathrm{~km}$ were surveyed by spotlight counts with 1,708 jackrabbits and 1,028 kangaroo rats (mostly Dipodomys ordi) recorded. After standardizing for unequal transect lengths and proportion of each habitat type surveyed, the proportion of prey species recorded in each habitat were: shrub-steppe (blacktail jackrabbit [BTJ]: 26.3\%, kangaroo rat [KR]: 34.9\%), grassland (BTJ: 24.9\%, KR: 36.3\%), stable dunes (BTJ: $4.8 \%$, KR: $13.8 \%$ ), greasewood (BTJ: $23.5 \%$, KR: $10.4 \%$ ), chenopod (BTJ: 5.3\%, KR: 0.4\%), pickleweed (BTJ: 2.8\%, KR: 0\%), and urban (BTJ: 12.4\%, KR: 4.2\%).
Sherman live traps were operated for 18,432 trap nights between June 1999 and September 2000 for a total of 474 individual captures representing 9 small mammal species (Table 1). Community diversity as well as the abundance of small mammals, varied between habitats. Shrub steppe and stable dunes were the most diverse, while chenopod, pickleweed, and urban habitats were most limited in species composition (Table 1). Proportional abundance of all small mammals trapped by habitat type was: shrub steppe $(25.6 \%)$, grassland $(7.5 \%)$, stable dune $(13.8 \%)$, greasewood $(18.9 \%)$, chenopod (12.3\%), pickleweed $(9.9 \%)$, and urban $(12.0 \%)$.

Pitfall arrays were operated for 630 array nights and days. Although dozens of invertebrate species were trapped using this method, it proved most appropriate for assessing the relative abundance of Mormon crickets (Anabrus simplex), Jerusalem crickets (Stenopelmatus fuscus), and scorpions (Centruroides spp.). Although Mormon crickets were present in all habitats except pickleweed, they were overwhelmingly found in grassland $(n=1,466,80 \%)$ and shrub steppe $(n=$ 290, 16\%) habitats (Table 2). Jerusalem cricket's had the highest abundance in stable dune $(n=17,38 \%)$, grassland ( $n=11,24 \%)$, and shrub steppe $(n=11,24 \%)$ habitats. The largest proportion of scorpions were in the stable dunes $(n=171,49 \%)$, with a more even distribution across shrubsteppe $(n=56,16 \%)$, chenopod $(n=45,13 \%)$, and grasslands $(n=34,10 \%)$.

A total of $54 \mathrm{~km}$ of flush counts were walked over the course of 15 summer months (Table 2). Grasshoppers (Orthoptera spp.) were found in grasslands $(n=1,219$, $72 \%)$, shrub steppe $(n=241,14 \%)$, and greasewood $(n=$ 100, 6\%). Lizards (Sceloporus graciosus, Uta stansburiana, and Cnemidophorus tigris) were found primarily in stable dune $(n=32,43 \%)$ and chenopod $(n=28,37 \%)$ habitats.

3.3. Dietary Preferences. During the study, 1,131 coyote (691 lowland, 440 highland) and 294 kit fox (98 lowland, 196 highland) scats were collected. Thirty-eight different prey species were found in the 2 canids' scat. Four (insect, rodent, kangaroo rat, rabbit) categories indicated sufficient importance in the diet ( $>10 \%$ occurrence) and were incorporated into the predicted distribution modeling (Figure 2). The percent occurrence of kangaroo rat remains of Dipodomys ordi and D. microps was $36.8 \%$ for kit foxes and $25.6 \%$ for coyotes. The rabbit species Sylvilagus nuttallii and Lepus californicus were represented in $11.1 \%$ of the prey occurrences of kit foxes and $31.9 \%$ of coyotes. The rodent category, including Reithrodontomys megalotis, Peromyscus maniculatus, P. truei, Onychomys leucogaster, and Ammospermophilus leucurus represented $19.9 \%$ of the kit fox and $14.8 \%$ of the coyote prey occurrences identified. Insects, which include Mormon crickets (Anabrus simplex), Jerusalem crickets (Stenopelmatus fuscus), and grasshoppers (Orthoptera spp.), comprised $19.3 \%$ of kit fox and $13 \%$ of coyote scat occurrences. Scorpions $(4.7 \%$ kit fox $[\mathrm{KF}], 1.1 \%$ coyote [Coy]), reptiles (1.1\% KF, 2.1\% Coy), birds (6.0\% KF, $2.7 \%$ Coy), ungulates $(0.2 \% \mathrm{KF}, 5.8 \% \mathrm{Coy})$, native fruits and vegetation $(0 \% \mathrm{KF}$, $2.2 \%$ Coy), miscellaneous mammals ( $0.2 \% \mathrm{KF}, 0.6 \%$ Coy), and anthropomorphic foods $(0.7 \% \mathrm{KF}, 0.3 \%$ Coy) all were found in amounts deemed too small to give weight to the 


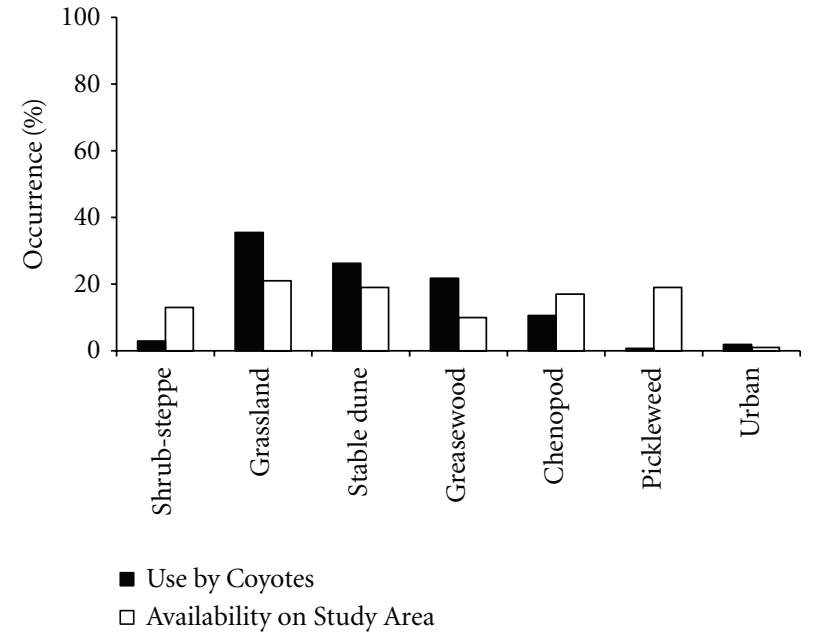

(a)

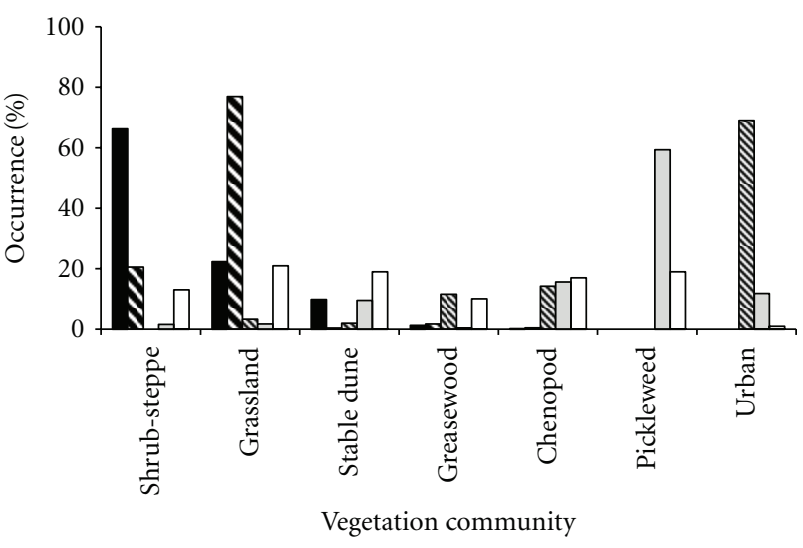

- Use by mountain foxes \ Use by grassland foxes $\mathbf{Q}$ Use by city foxes $\square$ Use by poverty foxes $\square$ Availability on study area

(b)

Figure 1: Comparison of habitat type availability and use by (a) all coyotes, and (b) kit foxes in mountain, grassland, city, and poverty landscapes, Dugway Proving Ground, Utah, 1999-2001.

TAble 1: Species and abundance of small mammals caught during 1999-2001, Dugway Proving Ground, Utah. PEMA: Peromyscus maniculatus, REME: Reithrodontomys megalotis, DIOR: Dipodomys ordi, ONLE: Onychomys leucogaster, NELE: Neotoma lepida, PETR: Peromyscus truei, AMLE: Ammospermophilus leucurus, DIMI: Dipodomys microps, PEPA: Perognathus parvus.

\begin{tabular}{|c|c|c|c|c|c|c|c|c|c|c|}
\hline Habitat & PEMA & REME & DIOR & ONLE & NELE & PETR & AMLE & DIMI & PEPA & No. of Species \\
\hline Shrub-steppe & 76 & 14 & 30 & 1 & 15 & 9 & 2 & 3 & 2 & 9 \\
\hline Grassland & 23 & 10 & 1 & 2 & 0 & 0 & 0 & 1 & 0 & 5 \\
\hline Stable dune & 28 & 16 & 26 & 11 & 0 & 4 & 4 & 0 & 1 & 7 \\
\hline Greasewood & 63 & 24 & 0 & 0 & 0 & 1 & 0 & 3 & 0 & 4 \\
\hline Chenopod & 53 & 2 & 0 & 2 & 0 & 0 & 0 & 0 & 0 & 3 \\
\hline Pickleweed & 44 & 0 & 1 & 0 & 0 & 0 & 2 & 0 & 0 & 3 \\
\hline Urban & 55 & 0 & 0 & 1 & 0 & 0 & 0 & 0 & 0 & 2 \\
\hline Total & 342 & 66 & 58 & 17 & 15 & 14 & 8 & 7 & 3 & \\
\hline
\end{tabular}

TABle 2: Abundance and distribution of prey species recorded during pitfall trapping and flush counts on Dugway Proving Ground, Utah, 1999-2001.

\begin{tabular}{|c|c|c|c|c|c|}
\hline \multirow{2}{*}{ Habitat } & \multicolumn{3}{|c|}{ Pitfalls } & \multicolumn{2}{|c|}{ Flush counts } \\
\hline & No. of Jerusalem crickets & No. of Mormon crickets & No. of Scorpions & No. of grasshoppers & No. of lizards \\
\hline Shrub-steppe & 11 & 290 & 56 & 241 & 3 \\
\hline Grassland & 11 & 1466 & 34 & 1219 & 1 \\
\hline Stable dune & 17 & 4 & 171 & 57 & 32 \\
\hline Greasewood & 0 & 38 & 20 & 100 & 1 \\
\hline Chenopod & 1 & 10 & 45 & 36 & 28 \\
\hline Pickleweed & 0 & 0 & 3 & 7 & 0 \\
\hline Urban & 5 & 10 & 20 & 30 & 10 \\
\hline Total & 45 & 1818 & 349 & 1690 & 75 \\
\hline
\end{tabular}

analysis. No scat of either species was found to contain kit fox remains. When combined for the calculation of predicted distribution models, the prey categories of insect, rodent, kangaroo rat, and rabbit, comprised $83.1 \pm 3.5 \%$ of the prey occurrences in the year-round diet of both species.
3.4. Modeling the Predicted Canid Distributions. Modeled for the study area, the predicted use of habitat types by kit foxes and coyotes was similar (Figure 3$)$. Grassland (36.2\% KF, $32.4 \%$ Coy), shrub-steppe (27.9\% KF, 27.7\% Coy), greasewood $(12.5 \% \mathrm{KF}, 15.6 \% \mathrm{Coy})$, and stable dune $(11.1 \% \mathrm{KF}$, 


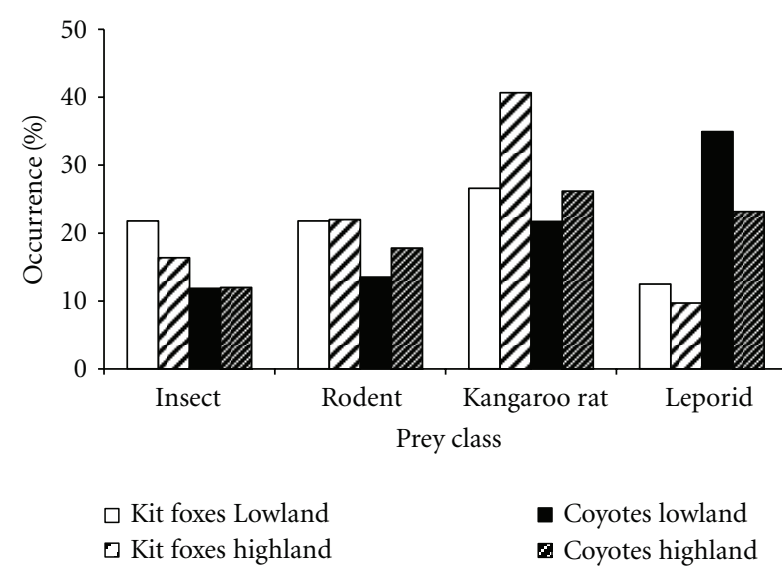

Figure 2: Percent occurrence of the top 4 prey classes found in kit fox and coyote scats and used to model predicted canid distribution, Dugway Proving Ground, Utah, 1999-2001.

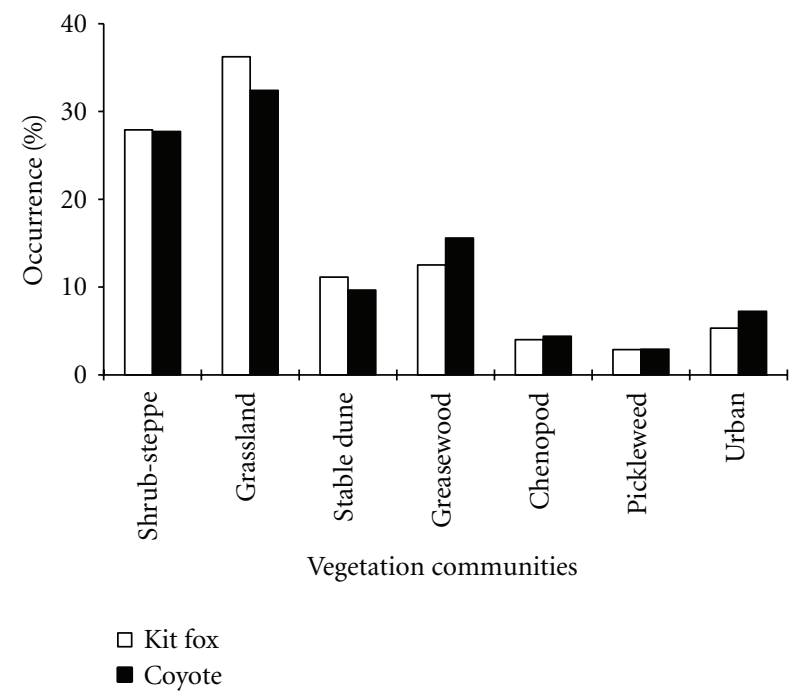

Figure 3: Predicted canid distributions for kit foxes and coyotes showing similar use of Dugway Proving Ground's 7 habitat types, Utah, 1999-2001.

9.7\% Coy) habitats were predicted to obtain the most use. Less productive urban $(5.3 \% \mathrm{KF}, 7.3 \%$ Coy) and chenopod (4.0\% KF, 4.4\% Coy) habitats were predicted to receive low amounts of use, and pickleweed (2.9\% KF, 2.9\% Coy) habitat virtually no use.

Comparisons between predicted and observed distributions indicated a closer adherence to the predicted model by coyotes than kit foxes (Figure 4). Based upon prey availability (relative abundance) among the 7 habitat types, the predicted distribution showed that in certain habitats with high prey and high coyote use, kit foxes avoided these habitats. Conversely, in habitats with low prey and low coyote use, kit foxes demonstrated much higher use than expected on prey abundance alone. For example, the predicted distribution for urban habitat indicated that the canids should use it 3.3\% of the time. Coyotes followed the prediction (3.1\% of locations) while kit foxes showed a high preference exceeding that predicted by prey availability $(16.0 \%$ of locations; $P<0.001)$.
Similarly, the predicted model indicated that pickleweed should be used $1.6 \%$ of the time based on prey, with coyotes using pickleweed $1.0 \%$ of the time and kit foxes using it $14 \%$ of the locations $(P<0.001)$. In contrast, the predicted distribution for grassland habitat showed that the canids should spend $36.9 \%$ of their time based upon prey abundance. Coyotes were located in grasslands $39.2 \%$ of the time, while kit foxes avoided that habitat (19\% of locations). Greasewood habitat was predicted to be used $16.4 \%$ of the time based on food availability, with coyotes preferring this habitat $(22.6 \%$ of locations) more than predicted by food alone, while kit foxes avoided this habitat ( $8 \%$ of locations; $P<0.001$ ). Overall, kit foxes showed strong avoidance of habitats utilized by coyotes, and their observed distribution was significantly different than the predicted distribution based upon food availability $\left(\chi^{2}=165.62, \mathrm{df}=6, P<0.001\right)$.

However, significant differences existed between most comparisons of observed versus predicted (modeled from prey distribution and abundance) distributions among both canids (Table 3 ). Relative to the predicted model, coyotes' observed distribution demonstrated both strong avoidance of shrub-steppe and preference for stable dune habitats. Observed habitat use by "mountain" foxes, "grassland" foxes, "city" foxes, and "poverty" foxes showed their strongest divergence from predicted distributions to occur as a result of preferential use of the habitat types associated with their landscape class namesake. Foxes demonstrated avoidance of virtually all other habitat classes (Table 3 ).

\section{Discussion}

Initial studies examining canid distributions on DPG showed differential use of its habitats by coyotes and kit foxes [17]. Given evidence of such space use, the conclusion could be made that although the dietary overlap of these 2 species is high, the canids remain in a stable state of sympatry through the implementation of spatial isolation mechanisms, a strategy by which kit foxes are able to stave off competitive exclusion by partitioning their space use with coyotes. Although evidence of isolation mechanism use by kit foxes was apparent, determining the current canid interactions required examination of the underlying causes of their distribution.

The results of the quantitative assessments conducted in this study demonstrated that habitats varied significantly in their prey resources. Both prey species' composition and abundance varied across the 7 habitat types examined, resulting in these habitats being differentially important to foraging canids. Pickleweed, chenopod, and urban habitats were characterized as being inhabited by the fewest number of individuals and species of small mammals, invertebrates, and lagomorphs. Although these habitats comprised a considerable proportion of the study area $(37 \%)$, only kit foxes spent substantial amounts of their time in these resourcescarce habitats (Figure 1(b)). Coyotes generally demonstrated an aversion to these 3 resource-poor habitats (Table 3 ). Pickleweed and chenopod, in addition to poor prey abundance, were also characterized by an acute, seasonal lack of free water. Although free water is not considered a limiting factor for kit foxes, its absence likely resulted in the 


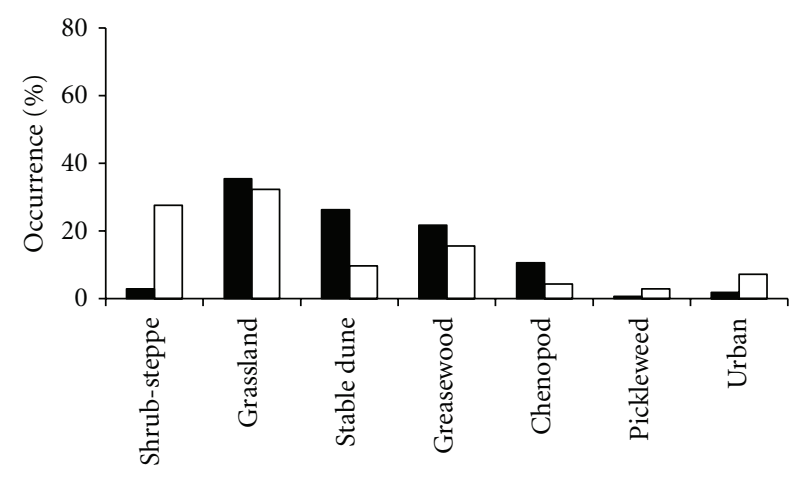

- Observed

$\square$ Predicted

(a)

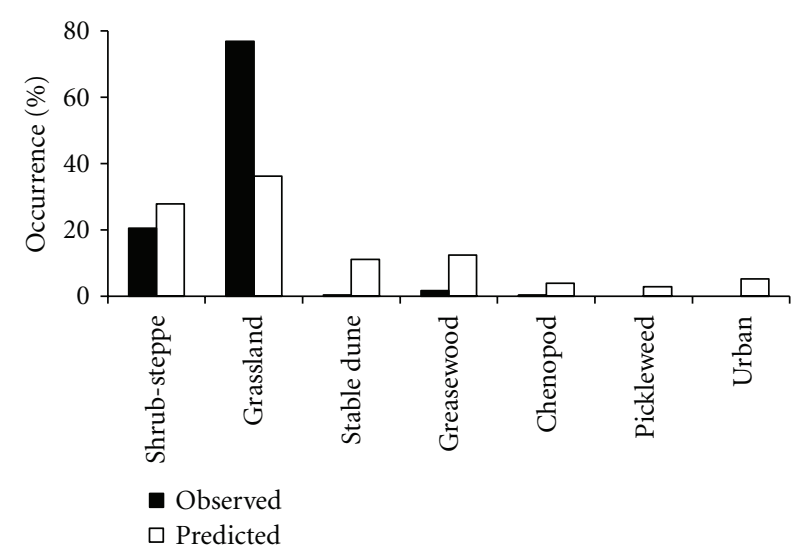

(c)

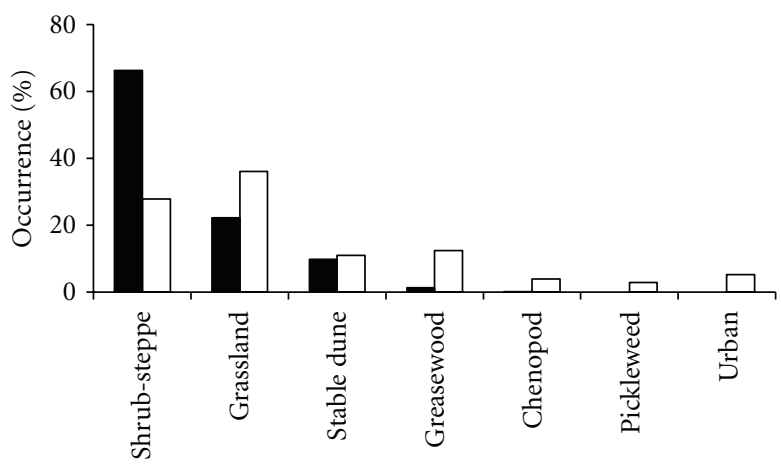

- Observed

$\square$ Predicted

(b)

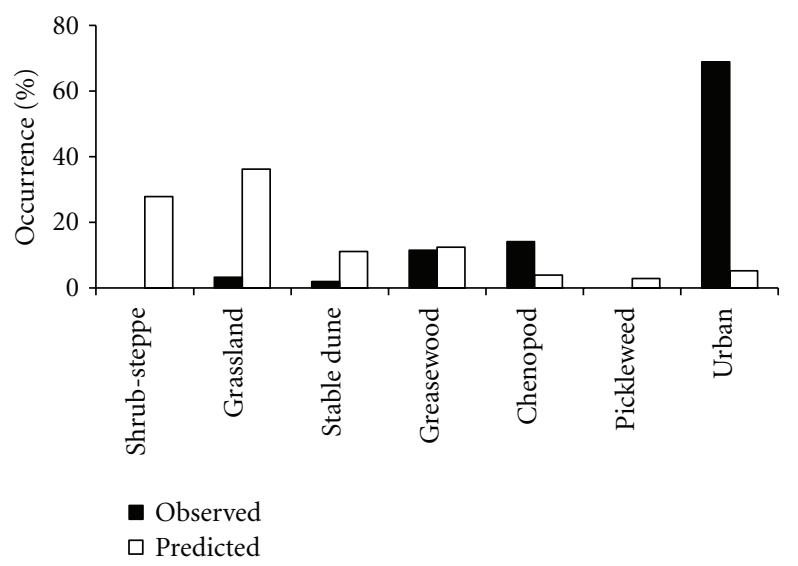

(d)

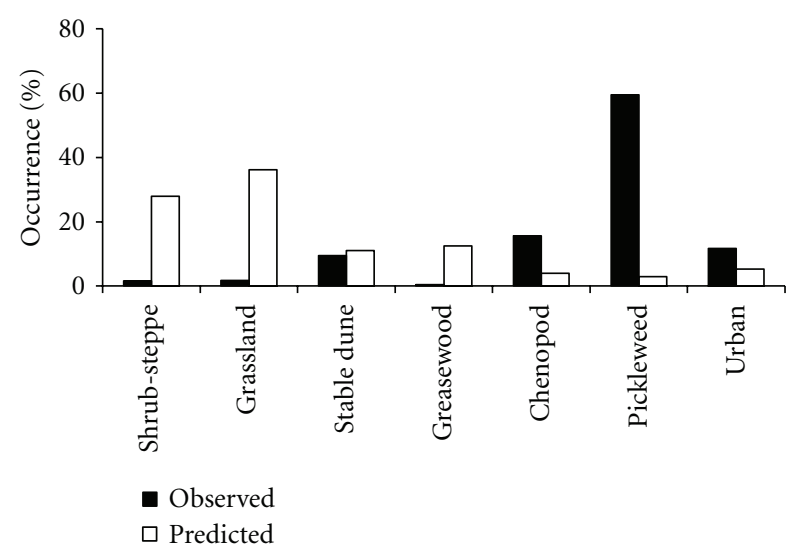

(e)

Figure 4: Observed and predicted canid distributions for (a) coyotes, (b) mountain kit foxes, (c) grassland kit foxes, (d) city kit foxes, and (e) poverty kit foxes, Dugway Proving Ground, Utah, 1999-2001.

further restriction of coyotes' use of these landscapes thereby enhancing their refuge-like qualities for kit foxes [50].

Although shrub-steppe, stable dune, grassland, and greasewood habitats held the highest values for diversity and abundance of the prey items favored by canid species, their use by kit foxes was less than predicted (Figure 1(b)). Of the kit foxes 4 landscape classes, only the "mountain" foxes and the single pair of foxes using the grasslands showed a preference for these habitat types. In fact, greasewood, with the 2nd highest abundance of small mammals and 3rd highest abundance of lagomorphs, was universally avoided by kit foxes and never averaged more than $15 \%$ of any landscape class spatial budget (Table 3 ). In contrast, the spatial distribution of coyotes overlapped heavily with those habitats 
TABLE 3: Comparisons between observed (lower and upper) and predicted canid distributions analyzed using the chi-square goodness-offit test [14]. Significant differences between distributions were detected using Bailey simultaneous confidence intervals. Habitats that were avoided were used less frequently than predicted; preferred habitats were used more than predicted.

\begin{tabular}{|c|c|c|c|c|c|c|}
\hline \multirow{2}{*}{ Habitat } & \multicolumn{3}{|c|}{ Proportion } & \multirow{2}{*}{ Selection } & \multirow{2}{*}{$\mathrm{df}$} & \multirow{2}{*}{$P$} \\
\hline & Lower & Upper & Predicted & & & \\
\hline \multicolumn{7}{|c|}{ Coyotes: observed versus predicted } \\
\hline Shrub-steppe & 0.0220 & 0.0385 & 0.2770 & Avoid & 6 & $<0.0001$ \\
\hline Grassland & 0.3329 & 0.3788 & 0.3240 & Prefer & 6 & $<0.05$ \\
\hline Stable Dune & 0.2426 & 0.2849 & 0.0970 & Prefer & 6 & $<0.0001$ \\
\hline Greasewood & 0.1989 & 0.2386 & 0.1560 & Prefer & 6 & $<0.0001$ \\
\hline Chenopod & 0.0920 & 0.1216 & 0.0440 & Prefer & 6 & $<0.0001$ \\
\hline Pickleweed & 0.0030 & 0.0125 & 0.0290 & Avoid & 6 & $<0.0001$ \\
\hline Urban & 0.0129 & 0.0262 & 0.0730 & Avoid & 6 & $<0.0001$ \\
\hline \multicolumn{7}{|c|}{ Mountain Foxes: observed versus predicted } \\
\hline Shrub-steppe & 0.6250 & 0.6992 & 0.2793 & Prefer & 6 & $<0.0001$ \\
\hline Grassland & 0.1915 & 0.2569 & 0.3624 & Avoid & 6 & $<0.0001$ \\
\hline Stable Dune & 0.0726 & 0.1232 & 0.1111 & & 6 & $>0.05$ \\
\hline Greasewood & 0.0057 & 0.0243 & 0.1251 & Avoid & 6 & $<0.0001$ \\
\hline Chenopod & 0.0000 & 0.0081 & 0.0400 & Avoid & 6 & $<0.0001$ \\
\hline Pickleweed & 0.0015 & 0.0043 & 0.0290 & Avoid & 6 & $<0.0001$ \\
\hline Urban & 0.0015 & 0.0043 & 0.0531 & Avoid & 6 & $<0.0001$ \\
\hline \multicolumn{7}{|c|}{ Grassland Foxes: observed versus predicted } \\
\hline Shrub-steppe & 0.1622 & 0.2524 & 0.2793 & Avoid & 6 & $<0.0001$ \\
\hline Grassland & 0.7181 & 0.8124 & 0.3624 & Prefer & 6 & $<0.0001$ \\
\hline Stable Dune & 0.0000 & 0.0165 & 0.1111 & Avoid & 6 & $<0.0001$ \\
\hline Greasewood & 0.0057 & 0.0362 & 0.1251 & Avoid & 6 & $<0.05$ \\
\hline Chenopod & 0.0001 & 0.0174 & 0.0400 & Avoid & 6 & $<0.05$ \\
\hline Pickleweed & 0.0030 & 0.0086 & 0.0290 & Avoid & 6 & $<0.0001$ \\
\hline Urban & 0.0030 & 0.0086 & 0.0531 & Avoid & 6 & $>0.05$ \\
\hline \multicolumn{7}{|c|}{ City Foxes: observed versus predicted } \\
\hline Shrub-steppe & 0.0023 & 0.0065 & 0.2793 & Avoid & 6 & $<0.0001$ \\
\hline Grassland & 0.0182 & 0.0537 & 0.3624 & Avoid & 6 & $<0.0001$ \\
\hline Stable Dune & 0.0087 & 0.0367 & 0.1111 & Avoid & 6 & $<0.0001$ \\
\hline Greasewood & 0.0863 & 0.1482 & 0.1251 & & 6 & $>0.05$ \\
\hline Chenopod & 0.1099 & 0.1773 & 0.0400 & Prefer & 6 & $<0.0001$ \\
\hline Pickleweed & 0.0023 & 0.0065 & 0.0290 & Avoid & 6 & $<0.001$ \\
\hline Urban & 0.6430 & 0.7322 & 0.0531 & Prefer & 6 & $<0.0001$ \\
\hline \multicolumn{7}{|c|}{ Poverty Foxes: observed versus predicted } \\
\hline Shrub-steppe & 0.0061 & 0.0315 & 0.2793 & Avoid & 6 & $<0.0001$ \\
\hline Grassland & 0.0073 & 0.0341 & 0.3624 & Avoid & 6 & $<0.0001$ \\
\hline Stable Dune & 0.0693 & 0.1267 & 0.1111 & & 6 & $>0.05$ \\
\hline Greasewood & 0.0003 & 0.0146 & 0.1251 & Avoid & 6 & $<0.0001$ \\
\hline Chenopod & 0.1239 & 0.1947 & 0.0400 & Prefer & 6 & $<0.0001$ \\
\hline Pickleweed & 0.5510 & 0.6458 & 0.0290 & Prefer & 6 & $<0.0001$ \\
\hline Urban & 0.0804 & 0.0531 & 0.0531 & Prefer & 6 & $<0.0001$ \\
\hline
\end{tabular}

supporting abundant prey resources. Overall, the distribution of coyotes closely matched the heterogeneity of the landscape in a manner that maximized their access to prey resources.

The diet of kit foxes and coyotes, as determined from scat analysis, indicates a high level of overlap of both the species and proportions of prey consumed [17]. Of the prey categories analyzed, insects, rodents, kangaroo rats, and lagomorphs were the 4 most important components of both canids' diets. This indicates that even when occupying relatively resource-poor habitats, kit foxes still managed to select prey items in proportions similar to those found in the diets 
of canids inhabiting higher quality habitats. This dietary resiliency likely requires more energy to maintain, either in the form of increased search time or larger territories, and thereby may have a negative effect on kit foxes' fitness. In essence, by avoiding competition with coyotes through spatial isolation, kit foxes must forage in suboptimal habitats to meet their dietary requirements $[51,52]$.

While it has been demonstrated that asymmetrical spatial partitioning of coyotes and kit foxes was occurring in association with high levels of dietary overlap, the question of whether the spatial distributions of the 2 canids were based on resources (by choice) or competition (by force) still needs to be addressed. Classical niche apportioning theory supports that a species' relative abundance is derived from the amount of limiting resources it controls [53-55]. It follows that in the absence of competitive forces, individuals should distribute themselves in patterns relative to the distribution of resources necessary for their survival and reproduction [56]. Although other researchers have successfully used removal of conspecifics to perturb faunal community conditions towards an ideal [57-59], such studies, when conducted on large, fecund, or protected species, may be too logistically difficult or politically unsavory to accomplish [60].

Given the extent of dietary overlap exhibited by the two canid species, it is not surprising that very similar predicted distributions were modeled for both coyotes and kit foxes (Figure 3). By demonstrating preferences for the same food resources in roughly the same proportions, it stood to reason that, in the absence of other selective forces, both canids should exhibit similar predicted distributions. However, while the observed distribution of coyotes paralleled the presence and absence of abundant prey, observed space use by kit foxes was clearly not in reaction to the distribution of food resources alone. Kit fox strategies, when examined from the context of space use, used geographic extremes (i.e., rugged terrain) not frequented by coyotes. The overall result was a reduction in fine-scale sympatry.

We made several assumptions when determining the predicted distribution of the two canids. Foremost was that prey abundance, in the absence of competition, was the only limiting resource governing the distribution canids on the study area. Denning sites, a factor which could possibly affect space use in canids, was assumed not to be limiting due to the flexibility in site selection observed during both historic and concurrent studies $[17,19]$. Differences in the vulnerability of prey or the energy required to forage across the different habitats was not considered. Limitations arising from the simplified nature of the model were deemed acceptable within the context; the model was intended to provide a conceptual starting point for identifying the effects of competitive exclusion.

Of special interest was the use of the shrub-steppe habitat by both species. The only habitat with significant amounts of topography, the shrub-steppe, was characterized by steep, rugged terrain and abundant prey resources. Observed use of this habitat was in contrast with the predicted model for both canids. In particular, kit foxes using the mountain landscape occupied the shrub-steppe to a very high degree, while coyotes were observed to largely avoid this rugged landscape
(Table 3). Landscape complexity and the energy required to forage in it likely decreased the use of shrub-steppe by coyotes, while simultaneously providing direct and indirect refuge for kit foxes in the form of improved cover and reduced competition. Similar benefits were provided by the structural complexity of the urban environments, allowing kit foxes to forage in nearby greasewood habitats normally dominated by coyotes. Foxes using the city landscape averaged 3 times the use of the greasewood habitat of the other 3 fox landscape classes combined. The unpredicted use of the shrub-steppe and urban habitats by kit foxes illustrates the complexity of habitat selection by a subordinate species in the presence of a very dominant species.

In conclusion, habitat selection by kit foxes appears to be a solution that reduces spatial overlap with coyotes while providing access to resources. Occupation of the spatial refuges provided by the rugged mountain ranges or the vacant alkali flats serve to both isolate and limit the number of kit fox territories possible on the landscape. Not unlike the characteristics exhibited by other remnant populations, DPG's kit foxes have high dispersal mortality and limited mixing of subpopulations [17]. We believe that under current conditions, the long-term sustainability of DPG's small kit fox population is questionable, and any conservation measures would need to address the effects of interspecific competition by coyotes.

\section{Acknowledgments}

Funding and support were provided by the U.S. ArmyDugway Proving Ground, Directorate of Environmental Programs, and the U.S. Department of Agriculture, Wildlife Services, National Wildlife Research Center, Logan Field Station at Utah State University. The authors acknowledge the dedicated field work of L. Blake, M. Criffield, E. Groth, T. Kozlowski, B. Louie, S. Lupis, D. Meier, D. Mummert, M. Panasci, and C. Winchester. They thank Hawkins and Powers Aviation, USDA-Wildlife Services pilots, and G. Gantz for aerial capture and telemetry support; Dugway Environmental personnel J. Martin, S. Plunkett, and J. Harn for consultation and advice; P. Terletzky for GIS support; S. Riley, D. Van Vuren, M. Wolfe, R. Schmidt, and A. Sih for critical reviews of the paper. Research protocols were approved by the Institutional Animal Care and Use Committees at the National Wildlife Research Center and Utah State University. Permits for capture of animals were obtained from the Utah Division of Wildlife Resources.

\section{References}

[1] V. Volterra, "Fluctuations in the abundance of a species considered mathematically," Nature, vol. 118, no. 2972, pp. 558$560,1926$.

[2] A. J. Lotka, "The growth of mixed populations: two species competing for a common food supply," Journal of the Washington Academy of Sciences, vol. 22, pp. 461-469, 1932.

[3] D. Lack, Darwin's Finches, Cambridge University Press, Cambridge, UK, 1944.

[4] J. D. Olden and N. L. Poff, "Toward a mechanistic understanding and prediction of biotic homogenization," The American Naturalist, vol. 162, no. 4, pp. 442-460, 2003. 
[5] T. Day and K. A. Young, "Competitive and facilitative evolutionary diversification," BioScience, vol. 54, no. 2, pp. 101-109, 2004.

[6] R. A. Armstrong and R. McGehee, "Competitive exclusion," The American Naturalist, vol. 115, pp. 151-170, 1980.

[7] P. Abrams, "The theory of limiting similarity," Annual Review of Ecology and Systematics, vol. 14, pp. 359-376, 1983.

[8] T. J. Case and M. E. Gilpin, "Interference competition and niche theory," Proceedings of the National Academy of Sciences of the United States of America, vol. 71, no. 8, pp. 3073-3077, 1974.

[9] T. K. Fuller and L. B. Keith, "Non-overlaping ranges of coyotes and wolves in northeastern Alberta," Journal of Mammalogy, vol. 62, pp. 403-405, 1981.

[10] D. R. Voigt and B. D. Earle, "Avoidance of coyotes by red fox families," Journal of Wildlife Management, vol. 47, pp. 852-857, 1983.

[11] S. M. Durant, "Competition refuges and coexistence: an example from Serengeti carnivores," Journal of Animal Ecology, vol. 67, no. 3, pp. 370-386, 1998.

[12] W. M. Arjo and D. H. Pletscher, "Behavioral responses of coyotes to wolf recolonization in northwestern Montana," The Canadian Journal of Zoology, vol. 77, no. 12, pp. 1919-1927, 1999.

[13] C. M. Thompson and E. M. Gese, "Food webs and intraguild predation: community interactions of a native mesocarnivore," Ecology, vol. 88, no. 2, pp. 334-346, 2007.

[14] W. M. Arjo, E. M. Gese, T. J. Bennett, and A. J. Kozolowski, "Changes in kit fox-coyote-prey relationships in the Great Basin Desert, Utah," Western North The American Naturalist, vol. 67, no. 4, pp. 389-401, 2007.

[15] C. W. Neu, C. R. Byers, and J. M. Peek, "A technique for analysis of utilization-availability data," Journal of Wildlife Management, vol. 38, pp. 541-545, 1974.

[16] D. H. Johnson, "The comparison of usage and availability measurements for evaluating resource preference," Ecology, vol. 61, pp. 65-71, 1980.

[17] A. J. Kozlowski, E. M. Gese, and W. M. Arjo, "Niche overlap and resource partitioning between sympatric kit foxes and coyotes in the Great Basin Desert of Western Utah," The American Midland Naturalist, vol. 160, no. 1, pp. 191-208, 2008.

[18] H. J. Egoscue, "Ecology and life history of the kit fox in Tooele County, Utah," Ecology, vol. 43, pp. 481-497, 1962.

[19] H. J. Egoscue, "Population dynamics of the kit fox in Western Utah," Bulletin of the Southern California Academy of Science, vol. 74, pp. 122-127, 1975.

[20] W. M. Arjo, T. J. Bennett, and A. J. Kozlowski, "Characteristics of current and historical kit fox (Vulpes macrotis) dens in the Great Basin Desert," The Canadian Journal of Zoology, vol. 81, no. 1, pp. 96-102, 2003.

[21] AGEISS Environmental, "Natural resources at U.S. Army Dugway Proving Ground 1952-1998: wildlife and habitat descriptions, historic and recent study summaries, conclusions, and future management recommendations," Directorate of Environmental Programs, U.S. Army Dugway Proving Ground, Utah, USA, 1998.

[22] V. Emrick and A. Hill, "Classification of great basin plant communities on dugway proving ground, Utah," Tech. Rep. number 99/30, U.S. Army Corps of Engineers, Construction Engineering Research Laboratory, 1999.

[23] M. W. Barrett, J. W. Nolan, and L. D. Roy, "Evaluation of a hand-held net-gun to capture large animals," Wildlife Society Bulletin, vol. 10, pp. 108-114, 1982.
[24] E. M. Gese, O. J. Rongstad, and W. R. Mytton, "Manual and net-gun capture of coyotes from helicopters," Wildlife Society Bulletin, vol. 15, pp. 444-445, 1987.

[25] A. J. Kozlowski, T. J. Bennett, E. M. Gese, and W. M. Arjo, "Live capture of denning mammals using an improved boxtrap enclosure: kit foxes as a test case," Wildlife Society Bulletin, vol. 31, no. 3, pp. 630-633, 2003.

[26] E. M. Gese, O. J. Rongstad, and W. R. Mytton, "Home range and habitat use of coyotes in southeastern Colorado," Journal of Wildlife Management, vol. 52, no. 4, pp. 640-646, 1988.

[27] R. K. Swihart and N. A. Slade, "Testing for independence of observations in animal movements," Ecology, vol. 66, no. 4, pp. 1176-1184, 1985.

[28] R. K. Swihart and N. A. Slade, "Influence of sampling interval on estimates of home-range size," Journal of Wildlife Management, vol. 49, no. 4, pp. 1019-1025, 1985.

[29] E. M. Gese, D. E. Andersen, and O. J. Rongstad, "Determining home-range size of resident coyotes from point and sequential locations," Journal of Wildlife Management, vol. 54, no. 3, pp. 501-506, 1990.

[30] D. L. Kramer and M. Bonenfant, "Direction of predator approach and the decision to flee to a refuge," Animal Behaviour, vol. 54, no. 2, pp. 289-295, 1997.

[31] S. Louis and M. Le Berre, "Adjustment of flight distances in Marmota marmota," The Canadian Journal of Zoology, vol. 78, no. 4, pp. 556-563, 2000.

[32] J. A. Bissonette, S. S. Sherburne, and D. R. Ramsey, "Analyzing telemetry data with a GIS-based vector structure," International Journal of Geographic Information Systems, vol. 8, pp. 533-543, 1994.

[33] L. E. T. Ostro, T. P. Young, S. C. Silver, and F. W. Koontz, "A geographic information system method for estimating home range size," Journal of Wildlife Management, vol. 63, no. 2, pp. 748-755, 1999.

[34] D. R. Griffin, Animal Minds, University of Chicago Press, Chicago, Ill, USA, 1992.

[35] R. C. Jennings, "A philosophical consideration of awareness," Applied Animal Behaviour Science, vol. 57, no. 3-4, pp. 201211, 1998.

[36] M. A. Elgar, "Predator vigilance and group size in mammals and birds: a critical review of the empirical evidence," Biological Reviews of the Cambridge Philosophical Society, vol. 64, no. 1, pp. 13-33, 1989.

[37] A. Frid and L. M. Dill, "Human-caused disturbance stimuli as a form of predation risk," Conservation Ecology, vol. 6, no. 1, p. 11, 2002.

[38] P. S. Morey, E. M. Gese, and S. Gehrt, "Spatial and temporal variation in the diet of coyotes in the Chicago metropolitan area," The American Midland Naturalist, vol. 158, no. 1, pp. 147-161, 2007.

[39] S. Cherry, "A comparison of confidence interval methods for habitat use-availability studies," Journal of Wildlife Management, vol. 60, no. 3, pp. 653-658, 1996.

[40] F. A. Leban, Resource Selection for Windows, Version: Beta 8, University of Idaho, Idaho, Moscow, Russia, 1999.

[41] M. Elbroch, Mammal Tracks and Sign: A Guide to North American Species, Stackpole Books, Mechanicsburg, Pa, USA, 2003.

[42] K. Ralls and D. A. Smith, "Latrine use by san joaquin kit foxes (Vulpes macrotis mutica) and coyotes (Canis latrans)," Western North The American Naturalist, vol. 64, no. 4, pp. 544-547, 2004.

[43] R. F. W. Barnes and S. C. Tapper, "A method for counting hares by spotlight,” Journal of Zoology, vol. 206, pp. 273-276, 1985. 
[44] K. Ralls and L. L. Eberhardt, "Assessment of abundance of San Joaquin kit foxes by spotlight surveys," Journal of Mammalogy, vol. 78, no. 1, pp. 65-73, 1997.

[45] R. B. Bury and P. S. Corn, "Evaluation of pitfall trapping in northwestern forests: trap arrays with drift fences," Journal of Wildlife Management, vol. 51, pp. 112-119, 1987.

[46] J. E. Funderburk, D. C. Herzog, T. P. Mack, and R. E. Lynch, "Sampling lesser cornstalk borer (Lepidoptera: Pyralidae) adults in several crops with reference to adult dispersion patterns," Environmental Entomology, vol. 14, pp. 452-458, 1985.

[47] S. L. Pimm and M. L. Rosenzweig, "Competitors and habitat use," Oikos, vol. 37, pp. 1-6, 1981.

[48] R. H. MacArthur and E. L. Pianka, "On optimal use of a patchy environment," The American Naturalist, vol. 100, pp. 603-609, 1966.

[49] M. E. Power, "Top-down and bottom-up forces in food webs: do plants have primacy?" Ecology, vol. 73, no. 3, pp. 733-746, 1992.

[50] R. T. Golightly and R. D. Ohmart, "Water economy of two desert canids: coyote and kit fox," Journal of Mammalogy, vol. 65, no. 1, pp. 51-58, 1984.

[51] G. D. Warrick, J. H. Scrivner, and T. P. O'Farrell, "Demographic responses of kit foxes to supplemental feeding," Southwestern Naturalist, vol. 44, no. 3, pp. 367-374, 1999.

[52] P. J. White and R. A. Garrott, "Population dynamics of kit foxes," The Canadian Journal of Zoology, vol. 77, no. 3, pp. 486493, 1999.

[53] J. H. Brown, "Two decades of homage to santa rosalia: toward a general theory of diversity," The American Zoologist, vol. 21, no. 4, pp. 877-888, 1981.

[54] G. E. Hutchinson, "Homage to Santa Rosalia, or why are there so many kinds of animals?" The American Naturalist, vol. 93, pp. 145-159, 1959.

[55] R. H. MacArthur, "On the relative abundance of bird species," Proceedings of the National Academy of Sciences, vol. 43, pp. 293-295, 1957.

[56] R. E. ricklefs, Ecology, W.H. Freeman, New York, NY, USA, 3rd edition, 1990.

[57] P. Ekerholm, L. Oksanen, T. Oksanen, and M. Schneider, “The impact of short-term predator removal on vole dynamics in an arctic-alpine landscape," Oikos, vol. 106, no. 3, pp. 457-468, 2004.

[58] S. E. Henke and F. C. Bryant, "Effects of coyote removal on the faunal community in western Texas," Journal of Wildlife Management, vol. 63, no. 4, pp. 1066-1081, 1999.

[59] S. M. Karki, E. M. Gese, and M. L. Klavetter, "Effects of coyote population reduction on swift fox demographics in southeastern Colorado," Journal of Wildlife Management, vol. 71, no. 8, pp. 2707-2718, 2007.

[60] R. E. Hoare, "Determinants of human-elephant conflict in a land-use mosaic," Journal of Applied Ecology, vol. 36, no. 5, pp. 689-700, 1999. 

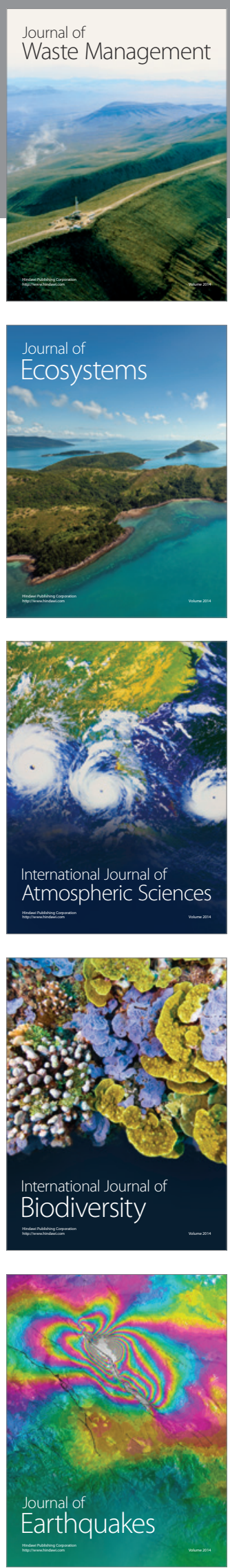
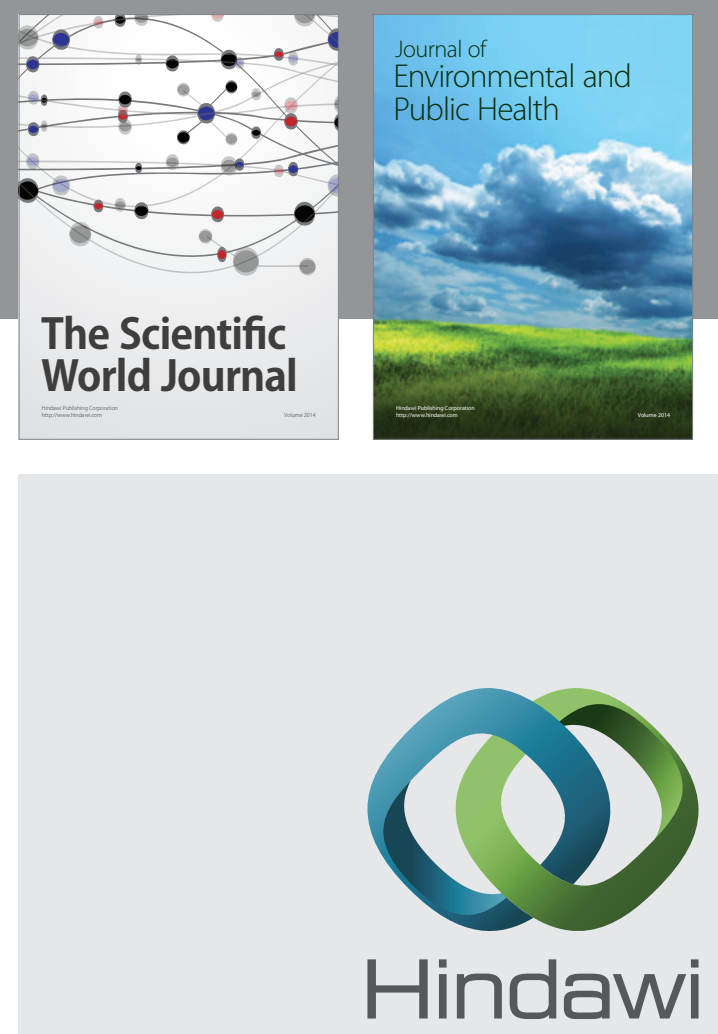

Submit your manuscripts at

http://www.hindawi.com
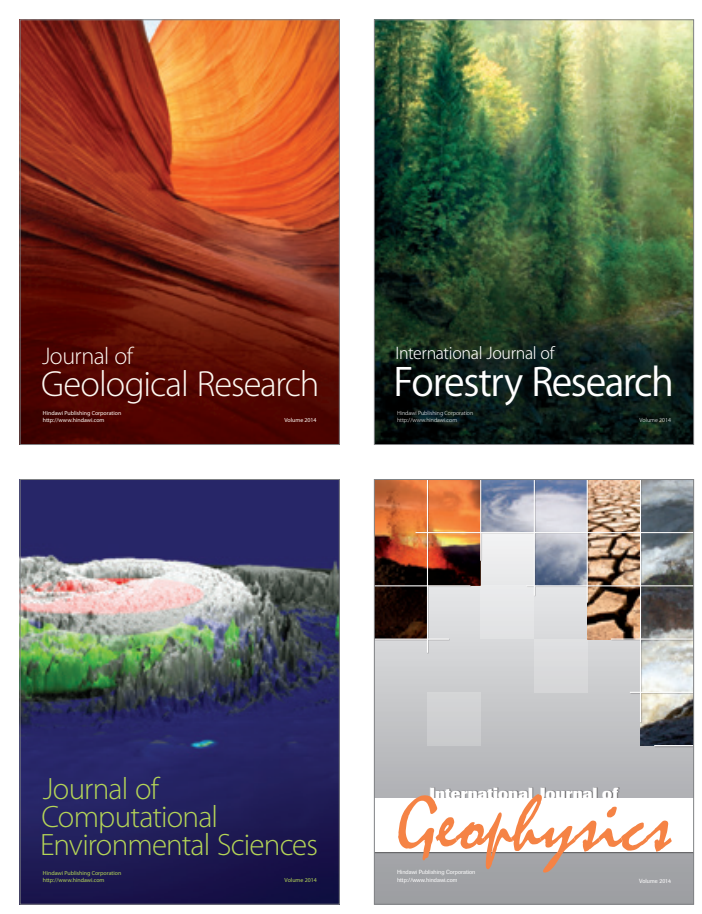
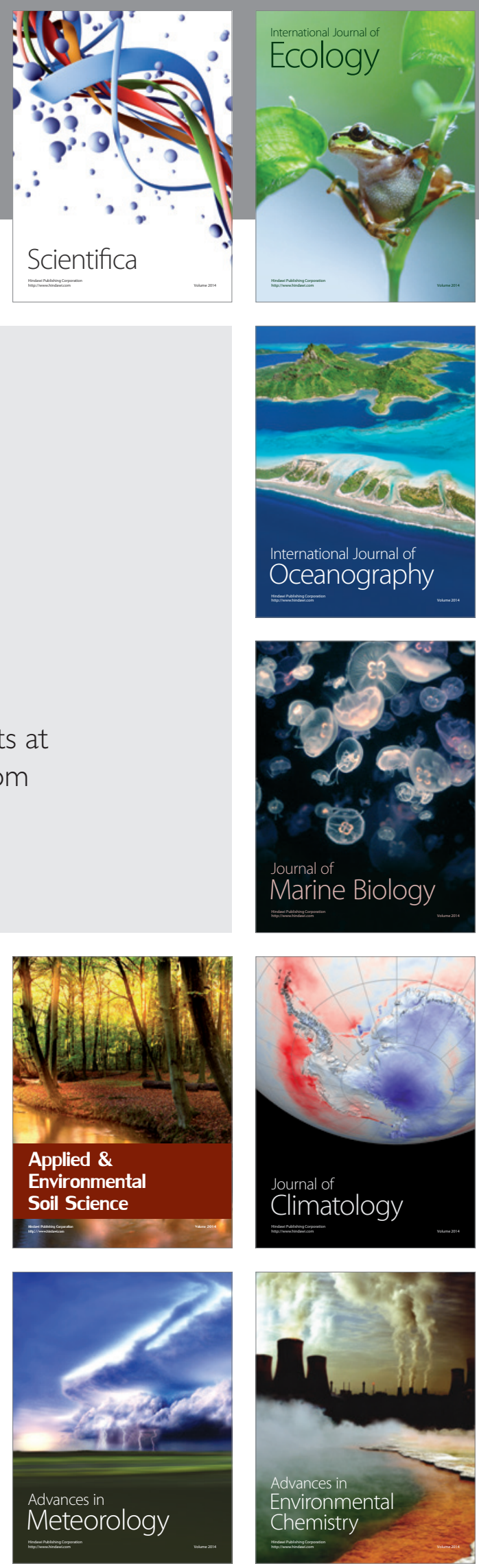